\title{
EXPORT ANALYSIS: AUTHORITY OF INFLATION AND EXCHANGE RATE IN ASEAN-8
}

\author{
Rika Mauliana \\ maulina89@mhs.unsyiah.ac.id \\ Abd. Jamal \\ Suriani \\ Universitas Syiah Kuala \\ Jl. Teuku Nyak Arief No.441, Syiah Kuala, Banda Aceh, Aceh 23111
}

received: 13/8/19; revised: 3/9/20; approved: 14/12/20

\begin{abstract}
This study was aimed to analyze the relationship of long-term and short-term equilibrium between exchange rates and inflation on exports in ASEAN-8 countries (Brunei Darussalam, Laos, Indonesia, Malaysia, Singapore, Philippines, Vietnam and Thailand) by using analysis model with the Autoregressive Distributed Lag (ARDL) panel from the period 1990 to 2017. The model selection was based on long-term and short-term capabilities with different stationary levels. The results revealed that in long-term the exchange rate and inflation had a dominant influence on export activities in ASEAN-8 countries, while inflation had a dominant influence on exports in short-term. This result proved that inflation had a large influence on the growth of the trade stability, if the cost of products and services continuously increased in the market mechanism, it will result in the increased public consumption. The excess liquidity in the market triggered the consumption or speculation which resulted in the non-compliance products distribution and the decline in currency value continuously.
\end{abstract}

Keywords: export; inflation; exchange rates; ARDL panel; long-term and short-term equilibrium

\section{INTRODUCTION}

The globalization widespread and economic status of ASEAN-8 which rose to a higher level also caused international financial transactions to experience a significant increase. The exchange rate contribution to economic negotiation activities is a very important factor to facilitate the operation of activities among countries, especially in the ASEAN Region (Hill, 2008). The exchange rate that non-constant number is a particular concern in economic activities especially in economic integration aspect. The implementation of exchange rates in a country will connote the characteristics of increasing and decreasing exchange rates, and impressions of economic activity (Zuhroh et al, 2007).

The results of a research conducted in China, Abbas et al, (2020) show that China's real exchange rate is structurally lower than other countries. The long-term and short-term effects of inequality Chinese currency have given various shocks to GDP, exports and imports. The overall results show that China's exchange rate is more sensitive to global trade, therefore it causes the instability in global trade. Hoang et al., (2020) prove that the increase of exchange rate contributes in improving the business environment, trade stability, controlling inflation and supporting economic growth in order to achieve macroeconomic stability.

Besides the exchange rate, the inflation rate also affects the exports as expressed by (Silviana, 2016) that the inflation rate weakens the trade stability in which the condition of goods the price continues to surge during a certain time period. It causes weakening competitiveness resulting in the decline of export value. Wulandari et al, (2019) show that the inflation rate in the long and short term is not caused by the unemployment rate but it caused by the increase of staples and fuel price which causes the customer interest decreases.

In the short-term, economic growth was seen from the increase of inflation rate but a high inflation rate has a bad impact in the long term. The high inflation surge affects the domestic goods price which is relatively more expensive than imported goods. If inflation occurs domestically, the price of domestic products is more expensive compared to imported products from abroad, therefore domestic products are difficult to compete with imported products. This will cause the export value smaller than the import value so that the trade 
balance has a deficit and deplete the country's foreign exchange reserves.

Wulandari et al., (2020) show that Indonesia's exports in the long term are influenced by global economic conditions which will reduce the value of commodities and export volumes, while in the short term, Indonesian exports rely on the input of raw materials and halffinished materials for industrial needs. This condition causes the pressure in annual net export.

Based on several empirical studies that study factors related to exports, including Kamin et al., (2003) comparing the response of inflation on the shift in exchange rate competitiveness in maintaining export growth. Cakrani et al., (2013) in Albania, Fani et al., (2011) in South Korea and Anshari et al., (2017) in 5 ASEAN analyzed the exchange rates, inflation and exports. Tunc et al., (2018) examined the role of exchange rate risk on the trade flow between countries which concentrated in small companies. Therefore, this study aimed to analyze the relationship of long-term and short-term equilibrium between exchange rates and inflation on export activities in ASEAN countries (Brunei Darussalam, Laos, Indonesia, Malaysia, Singapore, Philippines, Vietnam and Thailand).

\section{METHODS}

The data used in this research are secondary data in Time Series and Cross-Section data. The variables are inflation, exchange rates and Economic and Export Growth in ASEAN countries from 1990 to 2017. Overall, the data is obtained by the World Bank, International Financial Statistics and ASEANStat. The export used in this study is the total of all other market service funds provided to the whole world in the form of GDP percentage. The Inflation used is the consumer price index expressed in per cent while the exchange rate used is the exchange rate per US dollar. The economic growth used is the annual growth rate of GDP per capita expressed in per cent. Data in units of thousands or billions is transformed into logarithms.

This study uses the Auto Regressive Distributed Lag (ARDL) method which is a co-integration technique and was introduced by Pesaran et al. (2001) and Doğan et al. (2014) show with the following equations:

$\mathrm{Y}_{\mathrm{t}}=\alpha_{0}+\alpha_{1} \mathrm{t}+\sum_{\mathrm{i}=1}^{\mathrm{p}} \theta_{\mathrm{i}} \gamma_{\mathrm{t}-1}+\beta^{\prime} \mathrm{X}_{\mathrm{t}}+\sum^{\mathrm{q}-1}{ }_{\mathrm{i}=0} \beta^{*} \Delta \mathrm{X}_{\mathrm{t}-\mathrm{i}}+\mathrm{u}_{\mathrm{t}}$

$\Delta \mathrm{X}_{\mathrm{t}}=\mathrm{P}_{1} \Delta \mathrm{X}_{\mathrm{t}-1}+\mathrm{P}_{2} \Delta \mathrm{X}_{\mathrm{t}-2}+\ldots+\mathrm{P}_{\mathrm{i}} \Delta \mathrm{X}_{\mathrm{t}-\mathrm{i}}+\varepsilon_{\mathrm{t}}$

The equation for the combination of ARDL models with panel data is as follows:

$\mathrm{Y}_{\mathrm{j}, \mathrm{t}}=\alpha_{0}+\alpha_{1} \mathrm{t}+\sum_{\mathrm{i}=1}^{\mathrm{p}} \theta_{\mathrm{i}} \mathrm{Y}_{\mathrm{j}, \mathrm{t}-\mathrm{i}}+\beta^{\prime} \mathrm{X}_{\mathrm{i}, \mathrm{t}}+\sum^{\mathrm{q}-1 \mathrm{i}=0} \beta^{* \prime} \Delta \mathrm{X}_{\mathrm{j}, \mathrm{t}-\mathrm{1}}+\varepsilon_{\mathrm{j}, \mathrm{t}} \ldots$

To facilitate the research, the researcher then substituted equation (3) into the research variables, and then the equation is:

$$
\begin{aligned}
\Delta \mathrm{X}_{\mathrm{j}, \mathrm{t}}= & \alpha_{0 \mathrm{i}}+\sum_{\mathrm{i}}^{\mathrm{n}} \mathrm{i}_{\mathrm{i}=1} \alpha_{1 \mathrm{i}} \Delta \mathrm{INF}_{\mathrm{i}, \mathrm{t}-1}+\sum_{\mathrm{i}=1}^{\mathrm{n}} \alpha_{2 \mathrm{i}} \Delta \mathrm{ER}_{\mathrm{i}, \mathrm{t}-1}+\sum_{\mathrm{i}=1}^{\mathrm{n}} \alpha_{3 \mathrm{i}} \\
& \Delta \mathrm{GDP}_{\mathrm{i}, \mathrm{t}-\mathrm{1}}+\beta_{11} \mathrm{INF}_{\mathrm{j}, \mathrm{t}-1}+\beta_{21} \mathrm{ER}_{\mathrm{j}, \mathrm{t}-1}+\beta_{31} \operatorname{GDP}_{\mathrm{j}, \mathrm{t}-1}+\varepsilon_{\mathrm{j}, \mathrm{t}} \ldots(4)
\end{aligned}
$$

In which:

$$
\begin{array}{ll}
\mathrm{X} & =\text { ASEAN exports } \\
\text { INF } & =\text { ASEAN Inflation } \\
\text { ER } & =\text { Exchange Rate (exchange rate) } \\
\text { GDP } & =\text { Economic Growth in ASEAN }
\end{array}
$$

$\alpha_{1}, \alpha_{2}, \alpha_{3}=$ Coefficient Estimates Short Term

$\beta_{1}, \beta_{2}, \beta_{3}=$ Coefficient Estimates Long Term

$\alpha_{0} \quad=$ Constant

$\varepsilon_{\mathrm{t}} \quad=$ Error Term

The dependent variable of this research is exports are calculated by the value of all other market goods and services provided to the whole world, while the independent variable is the exchange rate calculated by the consumer price index, inflation with each country's currency per US dollar and GDP with the percentage of annual GDP growth rate per capita.

\section{RESULTS}

Before panel data were analysed, variable stationery must be tested to avoid false regression problems and needed to determine the integration of sequences before using co-integration techniques. Therefore, Levin, Lin \& Chu (LLC), Im, Pesaran and Shin (IPS), ADF Fisher Chi-Square (ADF Fisher) and PP-Fisher tests are used as a panel unit root tests.

Table 1 provides information, both observations on individual intercept and trend have no difference in each variable. The export variable and stationary inflation are at the level and the First Difference whereas in the exchange rate and GDP variables are not stationary or unit root at the level but are at the level of first difference. This indicates that each variable has a different level of stationarity and integration, then the next stage needs to be tested for cointegration.

Table 2 shows that there is a cointegration between exports, exchange rates, inflation and GDP at a significant level of 5 percent and 1 percent, so it can be concluded that there is a short-term to long-term relationship among variables. The observations made confirm that there is cointegration among exports, exchange rates, inflation and GDP at a significant level of 5 per cent and 1per cent so it can be concluded that there is a short-term to the long-term relationship among the four variables. In this research, the optimum lag is selected based on the value of the Akaike Information Criterion (AIC) generated by 16 lags. Therefore, the best lag selection with the smallest AIC value to the best lag by finding the smallest AIC value, this research using a lag of $3,4,4,4$.

The determination of the optimal lag has generated an estimation which can see the short-term and longterm effects on exports. Table 3 shows that in the short 
term inflation in this period did not affect exports but the previous period of one-year inflation had a positive effect on exports. This is evidenced by the coefficient that is positive with a value of 0.050 and at a significant level of 5 per cent. In the previous two-year period, inflation also had a positive effect on exports as evidenced by the coefficient that was positive with a value of 0.067 and was at a significant level of 5 per cent. For the long term, the inflation variable also has a positive effect at a significant level of $\alpha 0.01$ with a coefficient of 0.074 .

\section{DISCUSSION}

This result is consistent with the research conducted by Kiganda et al., (2017) stating that inflation has a significant positive long-term relationship with total exports. The results of his research concluded that the percentage increase in total exports increased longterm inflation in Kenya by $1.39 \%$. Whereas in the short term, the relationship of inflation to total exports has a negative effect and the existence of causality is the same as the total export toward inflation. In line with the results of research by Choudhry et al. (2015) that when the food ingredients exports increase, the inventories in the country decrease and the rise of food demand in a country will raise the price of food ingredients so that inflation will also escalate.

Furthermore, the results of research on inflation and exchange rates in ASEAN countries provide findings that inflation has a very positive impact on export activities in ASEAN countries as evidenced by positive and statistically significant values on the estimation results. When compared to the exchange rate, this dominance is not only owned by inflation but also by the exchange rate with a positive and significant value on the development of export activities in ASEAN countries, this is in accordance with the research previously carried out by Anshari et al. (2017) where inflation and exchange rates simultaneously have a significant effect on the value of exports in ASEAN-5 countries and are in line with research conducted by Fani et al. (2011), Pan \& Nguyen (2018), Tunc et al. (2018) and other research.

Table 4 illustrates the results of short-term estimation and duration of error correlation (ECT). Based on short-term estimates, the inflation and GDP variables in the previous three periods have a significant effect on ASEAN exports at the level of one per cent but the exchange rate variable in the previous three periods only Indonesia, Laos, Philippines, Thailand and Vietnam which have a significant influence on exports at one per cent.

Furthermore, ECT on the ARDL panel model is used to determine the speed of short-term balance adjustment towards the long term. In table 4, it is found a case of the influence of inflation and the exchange rate on exports in the short term in Indonesia is positive because of the Indonesian market price exceeds the price of foreign markets (some countries such as Malaysia and Thailand). Economic players choose to import products from other countries for consumption while the soaring prices of domestic products affect domestic demand, so the solution to economic transactions of domestically produced products is exported abroad. Based on previous research conducted by Ari Putra et al, (2017) also shows that inflation has a negative effect on exports, it is necessary to have controls carried out by the Government on inflation rate instability. In increasing domestic products, the increase in export value will be inversely proportional to the inflation rate.

The difference in influence obtained in the table is influenced by several factors, including the economic conditions in each country. The problem of inflation and the exchange rate in each country is one measure to measure the good or bad economic problems faced by a country.

\section{CONCLUSIONS}

This research shows that there are short-term to long-term relationships through the influence of inflation and the exchange rate on export activities in ASEAN countries. The results of the research show that inflation and exchange rates are one of the main factors that have a greater influence in the long term than in the short term. This is because the more inflation and the exchange rate of a country's currency increase, the greater the number of exports needed.

The increase in exports in ASEAN countries illustrates that inflation has a large influence. If prices of products and services continually increase in the market mechanism will result in increased public consumption, the excess liquidity in the market that triggers consumption or even speculation results in the non-compliance with the distribution of goods and the continuous decline in the value of the currency.

\section{REFERENCES}

Abbas, S., Nguyen, V. C., Yanfu, Z., \& Nguyen, H. T. 2020. The Impact of China Exchange Rate Policy on its Trading Partners : Evidence Based on the GVAR Model. Journal of Asian Finance, Economics and Business, 7(8), 131-141.

Anshari, M. F., Khilla, A. El, \& Permata, I. R. 2017. Analysis Of The Effect Of Inflation And Exchange On Exports In ASEAN Countries 5 Period Of 20122016. Journal of Info Artha, 1(2), 121-128.

Ari Putra, G. N., \& Sutrisna, I. K. 2017.The Effect Of Production And Inflation On Exports And Economic Growth in Indonesia. E-Jurnal Ekonomi Pembangunan Universitas Udayana, 6(1), 21652194. 
Cakrani, E., Resulaj, P., \& Kabello, L. K. 2013. Government Spending and Real Exchange Rate Case of Albania. European Journal of Sustainable Development, 303-310.

Choudhry, I., Hasan, M., \& Ali, M. 2015. The Relationship between Exports of Food Items and Inflation (CPI): Case Study of Pakistan, 4(6), 1-7.

Doğan, İ., Tülüce, N. S., \& Doğan, A. 2014. Dynamics of Health Expenditures in OECD Countries: Panel ARDL Approach. Theoretical Economics Letters, 04(08), 649-655.

Fang, W., Lai, Y., \& Miller, S. M. 2006. Export Promotion through Exchange Rate Changes: Exchange Rate Depreciation or Stabilization? Southern Economic Journal, 72(3), 611.

Fani, R., \& Putri, A. 2011. The Effect Of Inflation And Exchange Rate On Indonesia Export Of Textile And Electronic Commodities To South Korea (Study Before and After ASEAN Korea Free Trade Agreement in 2011), 35(1), 127-136.

Furuoka, F. 2009. Exports and economic growth in ASEAN countries: Evidence from panel data analysis. The IUP Journal of Applied Economics, $8(2), 7-16$.

Hill, C. W. L. 2008. Global Business Today 5th Edition.

Hoang, T. T., Thi, V. A. N., \& Minh, H. D. 2020. The impact of exchange rate on inflation and economic growth in Vietnam. Management Science Letters, 10(5), 1051-1060.

Kamin, S. B., \& Klau, M. 2003. A multi-country comparison of the linkages between inflation and exchange rate competitiveness. International Journal of Finance and Economics, 8(2), 167-184.

Kiganda, E., Obange, N., \& Adhiambo, S. 2017. The Relationship between Exports and Inflation in Kenya: An Aggregated Econometric Analysis. Asian Journal of Economics, Business and Accounting, $3(1), 1-12$.

Kurtović, S. 2017. The Effect of Depreciation of the Exchange Rate on the Trade Balance of Albania.
Review of Economic Perspectives, 17(2), 141-158. Kurtovic, S., Halili, B., \& Maxhuni, N. 2016. Bilateral Trade Elasticity BH versus its seven trade partners. Munich Personal RePEc Archive, (11543).

Nabli, M. K., \& Vèganzonès-Varoudakis, M. A. 2003. Exchange rate regime and competitiveness of manufactured exports: The case of MENA countries. Trade Policy and Economic Integration in the Middle East and North Africa: Economic Boundaries in Flux, 64-81.

Pan, M., \& Nguyen, H. 2018. Export and growth in ASEAN: does export destination matter? Journal of Chinese Economic and Foreign Trade Studies, 11(2), 122-131.

Pesaran, M. H., Shin, Y., \& Smith, R. J. 2001. Bounds testing approaches to the analysis of level relationships. Journal of Applied Econometrics, 16(3), 289-326.

Purusa, N. A., \& Istiqomah, N. 2018. Impact of FDI, COP, and Inflation to Export in Five ASEAN Countries, 19(1), 94-101.

Silviana, H. 2016. Analysis Of The Influence Of Exchange Rates And Inflation On The Trade Balance In Member Countries Of The Islamic Cooperation Organization. Universitas Islam Sunan Kalijaga: Yogyakarta.

Zuhroh, I., \& Kaluge, D. 2007. The Impact Of Growth In Real Exchange Rates On The Growth Of Indonesia's Trade Balance (An Application Of The Vector AutoRegressive, VAR Model) Journal of Indonesian Applied Economics, 1, 59-73.

Wulandari, D., Utomo, S. H., Narmadtya, B. S., \& Kamaludin, M. 2019. Nexus between Inflation and Unemployment: Evidence from Indonesia. Journal of Asian Finance, Economics and Business 6(2), 269-275.

Wulandari, D., Utomo, S. H., \& Narmaditya, B. S. 2020. The relationship between economic growth and macroeconomic indicators in Indonesia. Journal of International Studies, 13(2), 139-148. 
Table 1. Results of panel unit root tests

\begin{tabular}{lcccccccc}
\hline & \multicolumn{2}{c}{ LLC } & \multicolumn{2}{c}{ IPS } & \multicolumn{2}{c}{ ADF } & \multicolumn{2}{c}{ PP } \\
\cline { 2 - 8 } Variables & Intercept & $\begin{array}{c}\text { Intercept } \\
\text { and Trend }\end{array}$ & Intercept & $\begin{array}{c}\text { Intercept } \\
\text { and Trend }\end{array}$ & Intercept & $\begin{array}{c}\text { Intercept } \\
\text { and Trend }\end{array}$ & Intercept & $\begin{array}{c}\text { Intercept } \\
\text { and Trend }\end{array}$ \\
\hline LNX & -4.119 & -2.800 & -5.120 & -3.446 & 56.980 & 39.747 & 129.671 & 112.601 \\
& $(0.000)$ & $(0.002)$ & $(0.000)$ & $(0.000)$ & $(0.000)$ & $(0.000)$ & $(0.000)$ & $(0.000)$ \\
$\Delta$ LNX & -8.586 & -6.081 & -11.926 & -10.156 & 140.025 & 107.486 & 190.517 & 1758.22 \\
& $(0.000)$ & $(0.000)$ & $(0.000)$ & $(0.000)$ & $(0.000)$ & $(0.000)$ & $(0.000)$ & $(0.000)$ \\
INF & -8.741 & -7.185 & -5.969 & -5.246 & 68.337 & 58.374 & 59.064 & 55.274 \\
& $(0.000)$ & $(0.000)$ & $(0.000)$ & $(0.000)$ & $(0.000)$ & $(0.000)$ & $(0.000)$ & $(0.000)$ \\
$\Delta$ INF & -10.202 & -8.118 & -12.872 & -11.349 & 149.904 & 121.228 & 217.964 & 825.515 \\
& $(0.000)$ & $(0.000)$ & $(0.000)$ & $(0.000)$ & $(0.000)$ & $(0.000)$ & $(0.000)$ & $(0.000)$ \\
ER & -0.177 & 0.488 & 0.599 & 0.300 & 10.514 & 12.770 & 10.248 & 12.262 \\
& $(0.429)$ & $(0.687)$ & $(0.725)$ & $(0.618)$ & $(0.838)$ & $(0.689)$ & $(0.853)$ & $(0.725)$ \\
$\Delta$ ER & -5.263 & -3.905 & -5.433 & -3.605 & 60.200 & 40.545 & 90.780 & 64.659 \\
& $(0.000)$ & $(0.000)$ & $(0.000)$ & $(0.000)$ & $(0.000)$ & $(0.000)$ & $(0.000)$ & $(0.000)$ \\
GDP & 8.230 & 3.363 & 9.793 & 6.257 & 1.105 & 2.390 & 1.666 & 0.604 \\
& $(1.000)$ & $(0.999)$ & $(1.000)$ & $(1.000)$ & $(1.000)$ & $(1.000)$ & $(1.000)$ & $(1.000)$ \\
& -0.331 & -4.512 & -1.620 & -3.915 & 38.598 & 44.422 & 43.467 & 58.764 \\
& $(0.370)$ & $(0.000)$ & $(0.052)$ & $(0.000)$ & $(0.001)$ & $(0.000)$ & $(0.000)$ & $(0.000)$ \\
\hline SDP & & & & & & &
\end{tabular}

Source: Optimal Lag Test Results, (2019)

Table 2. Panel Cointegration

\begin{tabular}{lcc}
\hline Pedroni Cointegration Test & Statistic & Weighted Statistic \\
\hline Panel v-Statistic & $-1.521(0.936)$ & $-3.124(0.999)$ \\
Panel rho-Statistic & $-4.817(0.000)$ & $-3.487(0.000)$ \\
Panel PP-Statistic & $-13.37(0.000)$ & $-10.362(0.000)$ \\
Panel ADF-Statistic & $-3.940(0.000)$ & $-4.107(0.000)$ \\
Group rho-Statistic & $-3.005(0.001)$ & \\
Group PP-Statistic & $-13.285(0.000)$ & \\
Group ADF-Statistic & $-3.930(0.000)$ & \\
KAO Cointegration Test & t-statistic & \\
ADF & $-2.343(0.009)$ & \\
\hline
\end{tabular}

Table 3. Results of Estimation Model Panel ARDL

\begin{tabular}{lcccc}
\hline \multicolumn{1}{c}{ Variable } & Coefficient & SE & t-Statistic & Prob.* \\
\hline Long Run & & & & \\
\hline INF & 0.074 & 0.016 & 4.561 & $0.000^{* * *}$ \\
ER & 0.001 & 0.000 & 4.470 & $0.000^{* * *}$ \\
GDP & 0.000 & 2.730 & 3.790 & $0.000^{* * *}$ \\
\hline Short Run & & & & \\
\hline C & 19.439 & 8.066 & 2.409 & 0.017 \\
LOGExpor (-1) & -0.214 & 0.216 & -0.990 & 0.324 \\
LOGExpor (-2) & -0.029 & 0.136 & -0.216 & 0.828 \\
INF & 0.038 & 0.045 & 0.840 & 0.402 \\
INF (-1) & 0.050 & 0.024 & 2.094 & $0.039^{* *}$ \\
INF (-2) & 0.067 & 0.038 & 1.741 & $0.084^{*}$ \\
INF (-3) & 0.014 & 0.093 & 0.154 & 0.877 \\
ER & 2.676 & 1.662 & 1.610 & 0.110 \\
ER (-1) & -2.485 & 1.375 & -1.806 & $0.074^{*}$ \\
ER (-2) & 2.479 & 2.252 & 1.100 & 0.273 \\
ER (-3) & -1.089 & 0.935 & -1.164 & 0.247 \\
GDP & -0.001 & 0.000 & -1.661 & 0.100 \\
GDP (-1) & -0.001 & 0.001 & -0.772 & 0.442 \\
GDP (-2) & -0.000 & 0.001 & -0.171 & 0.863 \\
GDP (-3) & -0.002 & 0.002 & -1.279 & 0.203 \\
ECT(-1) & -0.664 & 0.269 & -2.468 & $0.015^{* *}$ \\
\hline Description** ** * signifcant at the $1 \%, 5 \%, 10 \%$ &
\end{tabular}

Description: $* * *, * *, *$ significant at the $1 \%, 5 \%, 10 \%$.

Source: Estimation Results Panel ARDL Model, (2019) 
Table 4. Effect of Short-Term (Short Run Model)

\begin{tabular}{|c|c|c|c|c|c|c|c|c|}
\hline \multirow[b]{2}{*}{ Variable } & \multicolumn{8}{|c|}{ ASEAN Counties } \\
\hline & $\begin{array}{c}\text { Brunei } \\
\text { Darussalam }\end{array}$ & Indonesia & Laos & Malaysia & Philippines & Singapore & Thailand & Vietnam \\
\hline $\mathrm{D}$ (INF) & $\begin{array}{c}0.024 \\
(0.619)\end{array}$ & $\begin{array}{c}-0.021 \\
(0.000)^{* * *}\end{array}$ & $\begin{array}{c}0.021 \\
(0.000)^{* * *}\end{array}$ & $\begin{array}{c}0.013 \\
(0.694)\end{array}$ & $\begin{array}{c}0.046 \\
(0.000)^{* * *}\end{array}$ & $\begin{array}{c}0.330 \\
(0.001)^{* * *}\end{array}$ & $\begin{array}{c}0.012 \\
(0.000)^{* * *}\end{array}$ & $\begin{array}{c}-0.121 \\
(0.000)^{* * *}\end{array}$ \\
\hline D (INF (-1)) & $\begin{array}{c}0.132 \\
(0.122)\end{array}$ & $\begin{array}{c}-0.007 \\
(0.000)^{* * *}\end{array}$ & $\begin{array}{c}-0.003 \\
(0.002)^{* * *}\end{array}$ & $\begin{array}{c}0.132 \\
(0.083)^{*}\end{array}$ & $\begin{array}{c}0.100 \\
(0.000)^{* * *}\end{array}$ & $\begin{array}{c}0.000 \\
(0.995)\end{array}$ & $\begin{array}{c}0.079 \\
(0.000)^{* * *}\end{array}$ & $\begin{array}{l}-0.031 \\
(0.000)\end{array}$ \\
\hline D (INF (-2)) & $\begin{array}{c}0.210 \\
(0.013)\end{array}$ & $\begin{array}{c}0,001 \\
(0,000)^{* * *}\end{array}$ & $\begin{array}{c}-0.023 \\
(0.000)^{* * *}\end{array}$ & $\begin{array}{c}0.260 \\
(0.010)^{* *}\end{array}$ & $\begin{array}{c}0.067 \\
(0.000)^{* * *}\end{array}$ & $\begin{array}{c}0.051 \\
(0.212)\end{array}$ & $\begin{array}{c}-0.034 \\
(0.000)^{* * *}\end{array}$ & $\begin{array}{c}0.006 \\
(0.000)\end{array}$ \\
\hline D (INF (-3)) & $\begin{array}{c}-0.552 \\
(0.001)^{* * *}\end{array}$ & $\begin{array}{c}0.001 \\
(0.000)^{* * *}\end{array}$ & $\begin{array}{c}0.012 \\
(0.000)^{* * *}\end{array}$ & $\begin{array}{c}0.399 \\
(0.001)^{* * *}\end{array}$ & $\begin{array}{c}0.016 \\
(0.008)^{* * *}\end{array}$ & $\begin{array}{c}0.150 \\
(0.011)^{* *}\end{array}$ & $\begin{array}{c}0.055 \\
(0.000)^{* * *}\end{array}$ & $\begin{array}{c}0.037 \\
(0.000)\end{array}$ \\
\hline D (ER) & $\begin{array}{r}11.603 \\
(0.776)\end{array}$ & $\begin{array}{c}5.530 \\
(0.000)^{* * *}\end{array}$ & $\begin{array}{c}-0.001 \\
(0.000)^{* * *}\end{array}$ & $\begin{array}{c}1.158 \\
(0.528)\end{array}$ & $\begin{array}{c}-0.016 \\
(0.001)^{* * *}\end{array}$ & $\begin{array}{c}8.724 \\
(0.681)\end{array}$ & $\begin{array}{c}-0.053 \\
(0.000)^{* * *}\end{array}$ & $\begin{array}{l}-5.210 \\
(0.000)\end{array}$ \\
\hline D (ER (-1)) & $\begin{array}{l}-9.593 \\
(0.804)\end{array}$ & $\begin{array}{c}0.000 \\
(0.000)^{* * *}\end{array}$ & $\begin{array}{c}0.001 \\
(0.000)^{* * *}\end{array}$ & $\begin{array}{l}-3.219 \\
(0.132)\end{array}$ & $\begin{array}{c}0.114 \\
(0.000)^{* * *}\end{array}$ & $\begin{array}{l}-7.282 \\
(0.729)\end{array}$ & $\begin{array}{c}0.096 \\
(0.000)^{* * *}\end{array}$ & $\begin{array}{l}-0.001 \\
(0.000)\end{array}$ \\
\hline D (ER (-2)) & $\begin{array}{l}18.175 \\
(0.369)\end{array}$ & $\begin{array}{c}-7.380 \\
(0.000)^{* * *}\end{array}$ & $\begin{array}{c}0.000 \\
(0.000)^{* * *}\end{array}$ & $\begin{array}{l}-0.099 \\
(0.927)\end{array}$ & $\begin{array}{c}-0.029 \\
(0.000)^{* * *}\end{array}$ & $\begin{array}{c}1.738 \\
(0.932)\end{array}$ & $\begin{array}{c}0.051 \\
(0.000)^{* * *}\end{array}$ & $\begin{array}{l}-0.002 \\
(0.000)\end{array}$ \\
\hline D (ER (-3)) & $\begin{array}{l}-7.383 \\
(0.854)\end{array}$ & $\begin{array}{c}-2.460 \\
(0.000)^{* * *}\end{array}$ & $\begin{array}{c}0,000 \\
(0,000)^{* * *}\end{array}$ & $\begin{array}{c}0.602 \\
(0.720)\end{array}$ & $\begin{array}{c}0.013 \\
(0.002)^{* * *}\end{array}$ & $\begin{array}{l}-1.911 \\
(0.900)\end{array}$ & $\begin{array}{c}-0.037 \\
(0.000)^{* * *}\end{array}$ & $\begin{array}{l}-0.000 \\
(0.000)\end{array}$ \\
\hline $\mathrm{D}(\mathrm{GDP})$ & $\begin{array}{c}0.000 \\
(0.000)^{* * *}\end{array}$ & $\begin{array}{c}0.000 \\
(0.000)^{* * *}\end{array}$ & $\begin{array}{c}-0.004 \\
(0.000)^{* * *}\end{array}$ & $\begin{array}{c}0.000 \\
(0.000)^{* * *}\end{array}$ & $\begin{array}{c}-0.001 \\
(0.000)^{* * *}\end{array}$ & $\begin{array}{c}4.460 \\
(0.000)^{* * *}\end{array}$ & $\begin{array}{c}-0.001 \\
(0.000)^{* * *}\end{array}$ & $\begin{array}{l}-0.004 \\
(0.000)\end{array}$ \\
\hline $\mathrm{D}(\mathrm{GDP}(-1))$ & $\begin{array}{c}0.000 \\
(0.000)^{* * *}\end{array}$ & $\begin{array}{c}0.000 \\
(0.000)^{* * *}\end{array}$ & $\begin{array}{c}-0.002 \\
(0.000)^{* * *}\end{array}$ & $\begin{array}{c}-0.001 \\
(0.000)^{* * *}\end{array}$ & $\begin{array}{c}0.003 \\
(0.000)^{* * *}\end{array}$ & $\begin{array}{c}-6.640 \\
(0.000)^{* * *}\end{array}$ & $\begin{array}{c}0.002 \\
(0.000)^{* * *}\end{array}$ & $\begin{array}{l}-0.013 \\
(0.000)\end{array}$ \\
\hline $\mathrm{D}(\mathrm{GDP}(-2))$ & $\begin{array}{c}0.000 \\
(0.000)^{* * *}\end{array}$ & $\begin{array}{c}-0.002 \\
(0.000)^{* * *}\end{array}$ & $\begin{array}{c}0.008 \\
(0.000)^{* * *}\end{array}$ & $\begin{array}{c}0.001 \\
(0.000)^{* * *}\end{array}$ & $\begin{array}{c}-0.000 \\
(0.000)^{* * *}\end{array}$ & $\begin{array}{c}0.000 \\
(0.000)^{* * *}\end{array}$ & $\begin{array}{c}-0.001 \\
(0.000)^{* * *}\end{array}$ & $\begin{array}{c}-0.008 \\
(0.000)\end{array}$ \\
\hline $\mathrm{D}(\mathrm{GDP}(-3))$ & $\begin{array}{c}0.000 \\
(0.000)^{* * *}\end{array}$ & $\begin{array}{c}0.000 \\
(0.000)^{* * *}\end{array}$ & $\begin{array}{c}-0.002 \\
(0.000)^{* * *}\end{array}$ & $\begin{array}{c}-8.060 \\
(0.000)^{* * *}\end{array}$ & $\begin{array}{c}-0.002 \\
(0.000)^{* * *}\end{array}$ & $\begin{array}{c}-5.310 \\
(0.000)^{* * *}\end{array}$ & $\begin{array}{c}1.270 \\
(0.000)^{* * *}\end{array}$ & $\begin{array}{l}-0.019 \\
(0.000)\end{array}$ \\
\hline ECT (-1) & $\begin{array}{c}-1.203 \\
(0.009) * * *\end{array}$ & $\begin{array}{c}0.001 \\
(0.001)^{* * *}\end{array}$ & $\begin{array}{c}-0.105 \\
(0.000)^{* * *}\end{array}$ & $\begin{array}{c}-0.260 \\
(0.011)^{* *}\end{array}$ & $\begin{array}{c}-1.819 \\
(0.000)^{* * *}\end{array}$ & $\begin{array}{c}-0.046 \\
(0.089)^{*}\end{array}$ & $\begin{array}{c}-0.241 \\
(0.000)^{* * *}\end{array}$ & $\begin{array}{l}-1.640 \\
(0.000) \\
\end{array}$ \\
\hline
\end{tabular}

Description: $* * *, * *, *$ significant at the $1 \%, 5 \%, 10 \%$.

Source: Short Term Test Results, (2018) 